\title{
Accelerated Internationalization in Emerging Markets: Empirical Evidence from Brazilian Technology-Based Firms
}

\author{
Fernanda C. Ferreira Ribeiro', Moacir Oliveira De Miranda Jr.2, Felipe M. Borini ${ }^{3}$, Roberto Bernardes ${ }^{4}$
}

\begin{abstract}
This article investigates the external factors driving the accelerated internationalization of technology-based firms (TBFs) in the context of an emerging market, Brazil. This type of firm is typically called born global and has been reported mainly in the high-technology sectors and from the developed countries. Our research is survey-based, and a questionnaire was applied to the small and medium Brazilian TBFs. Logistic regression was used to test the research hypotheses. The results suggest that the new and small Brazilian technology-based firms, which followed an accelerated internationalization process, are most likely to be integrated into a global production chain. The results also indicate that the TBFs that take more than 5 years to enter the international market benefit more from the location in an innovation habitat, the partnerships in the home country, and the pro-internationalization government policies. Therefore, this research contributes to a better understanding of the phenomenon and points to new perspectives for future studies on TBFs from emerging markets.
\end{abstract}

Keywords: internationalization, emerging economies, technology-based firms, born globals.

\footnotetext{
'Assistant Professor, FEI - School of Industrial Engineering, Rua Tamandare, 688, Liberdade, 0I525-000, São Paulo, Brazil. E-mail: fribeiro@fei.edu.br

${ }^{2}$ Associate Professor, University of São Paulo,Av. Prof. Luciano Gualberto, 908 - sala E-196, 05508-0 I0, Sao Paulo, Brazil.

${ }^{3}$ Associate Professor, ESPM - Escola Superior de Propaganda e Marketing, Rua Doutor Álvaro Alvim, I2, Vila Mariana, 040I8-0I0 São Paulo, SP, Brazil.

${ }^{4}$ Associate Professor, FEl - School of Industrial Engineering, Rua Tamandare, 688, Liberdade, 0I 525-000, São Paulo, Brazil.
} 


\section{Introduction}

Our paper focuses on small companies in the high-tech sectors that have followed an early, accelerated process of internationalization (Knight and Kim, 2009; Oviatt and Mcdougall, 1994) rather than the patterns of internationalization predicted by the prominent IB theories, (Dunning, 1980). We observe an emerging country context, Brazil. Emerging markets are defined as countries in the process of structural reforms and rapid economic growth (measured by the gross national product per capita) but are still below the developed economies (World Bank, 20I2). Most of the emerging market countries are opening their borders to the flow of international trade and investments (Kanna and Palepu, 2010, Persinger et al, 2007).

Reporting on the internationalization of new ventures, the most referenced studies have been based on developed countries, such as the United States (Knight and Kim, 2009; Oviatt and Mcdougall, 1994) and the European countries (Zucchella at. al. 2007). However, it is questionable to what extent the studies from developed economies fully capture the dynamics of accelerated internationalization in emerging markets (Kiss et al., 2012). In recent years, studies have noted the appearance of the born global firms in different regions of the world. Evidence from Latin America indicates software born global firms from Costa Rica (Lopez et al., 2009) and Brazil (Dib, et al., 20 I0). In Asia, studies include research on the Chinese international new ventures (Zou and Ghauri, 20I0) and the Indian IT companies (Varma, 20II).

The empirical studies on accelerated internationalization have focused significant attention on the founders/entrepreneurs because these individuals embody most of the principal resources (and capabilities) of these firms at startup (Rialp et al, 2005). Articulation of the unique internal resources enables new and small firms to outperform their competitors and internationalize more rapidly (Alvarez and Barney, 2002; Knight and Kim, 2009). While organizational and entrepreneurial factors are frequent in the studies on accelerated internationalization, the analysis of the external environment is not as frequent (Fernhaber et al., 2007; Zahra and George, 2002). Zahra and George (2002) attribute this lack of research to the complexity and variety of the possible combinations of the external factors that might have some influence.

This paper examines accelerated internationalization by $(I)$ identifying the influential external variables for accelerated internationalization and (2) testing these variables in a sample of small Brazilian technology-based firms to determine whether the same external factors reported in the literature can explain early internationalization in an emerging market. The analysis is performed by comparing the behav- ior of firms that had internationalized in an accelerated manner with the traditionally internationalized firms.

We first examined the literature on accelerated internationalization and identified the studies that address the phenomenon in emerging markets. Then, we focused on the external variables that may impact a firm's choice of an accelerated internationalization path. We then present the hypotheses, followed by our research design. Finally, we discuss our findings and contributions.

\section{Literature review \\ The Accelerated Internationalization in Emerging Economies}

Studies on accelerated internationalization are relatively recent, dating back approximately more than a decade (Knight and Kim, 2009; Rialp et al., 2005; Oviatt and Mcdougall, 1994). In the literature, the different denominations of companies characterized by accelerated internationalization appear as variations of the same phenomenon (Rialp et al., 2005). Such denominations include international new ventures (Oviatt and Mcdougall, 1994), born globals (Knight and Kim, 2009), global start-ups (Madsen and Servais, 1995), and new-technology-based firms (Autio et al., 2000), among others. More than a decade after the pioneering study by Oviatt and Mcdougall (1994), there are no general definitions of the concept. Regardless of the denomination chosen, the phenomenon is often presented as companies that establish activities abroad from their foundation, or a few years thereafter, with little or no experience in the domestic market. In addition, born global firms were identified in a quantity of different industries (Madsen and Servais 1997), but the literature review conducted by Rialp et al. (2005) indicated that most studies had looked at firms in the high-tech industries.

In recent works, Keupp and Gassmann (2009) and Kiss et al. (20I2) have tried to consolidate the literature. However, it is challenging to make a complete literature review due to the lack of consensus of the phenomenon. The most recurrent criteria that have been adopted are the following (Rialp et al., 2005; Dib et al., 20I0): (I) the founding date (most authors believe that the born global firms emerged after 1990); (2) the international activities after the foundation, (varying from 2 to 15 years depending on the home country); (3) the percentage of revenue arising from foreign operations (ranging from $5 \%$ to $75 \%$ depending on the size of the domestic market); (4) and the range and location of the markets).

There is no consensus regarding the factors explaining the speed of the internationalization process (Dib et al., 20l0), but certain factors have been noted as potentially being the main drivers of an accelerated internationalization process: (I) Internal factors (Knight and Kim, 2009). The possession 
of unique assets was found to be positively related to being a born global (Rialp et al. 2005).

(2) Factors related to the entrepreneurs. McDougall et al. (1994) viewed the entrepreneur as an individual who is more aware of opportunities than others, has a higher tolerance for risk and often has social capital (the use of personal or professional relationships and networks).

(3) External Factors (Zahra and George, 2002). Country size (Bloodgood et al., 1996) seems to be one factor influencing accelerated internationalization, with firms in the small countries having easier geographical access to neighboring markets. The size of the domestic market also appears influential, as countries with small domestic markets (Gabrielsson, et al, 2004) seem to favor accelerated internationalization. Other factors such as the institutional (Bruton et al., 2008) and government support (Bell and McNaughton, 2000 ) and the strategic alliances and networking (Coviello, 2006) may influence the likelihood of new venture internationalization. In the next session, we detail the influence of external factors on the accelerated internationalization.

These three groups of factors have been consistently identified as essential to the development and success of the born-global firms (Dib et al., 2010). However, the empirical studies of accelerated internationalization have focused predominantly on the organizational (internal) and entrepreneurial factors. The analysis of the external environment is not as frequent (Fernhaber et al., 2008; Zahra and George, 2002).

Zahra and George (2002) attribute this lack of research to the complexity and variety of the possible combinations of external factors that might have some influence. Despite the relevance of the organizational (internal) and entrepreneurial factors in creating the conditions for accelerated internationalization, these factors alone cannot explain the phenomenon. This suggests that other factors, external to the firm, might explain, at least partially, the new phenomenon. Certain research efforts have been developed in the last 15 years to understand the factors influencing accelerated internationalization from the perspective of the variables external to the firm.

\section{External Factors Influencing Accelerated Interna- tionalization}

In this paper, we are investigating the role of external factors in the home country environment in the accelerated internationalization of a company. For young and small firms, the external factors in the home country are viewed as vital to the company's operations. Often, these companies operate in the international market as exporters and do not have foreign direct investment (Oviatt and Mcdougall, 1994). They cannot fully benefit from the resources of the host country. Thus, the competitive environment of the home country can allow or restrict the strategic choices regarding internationalization made by the local companies (Fahy, 2002).

Firms from every country do not have equal propensities to internationalize rapidly because the external factor conditions in the home country around the world are different (Dib et al, 2010; Zucchella et. al. 2007). The studies on born globals from emerging markets reveal certain differences in the behavior of the company compared with the developed economies (Kiss et al, 2012). Kiss et al, (2012) reviewed 88 studies on the born globals from emerging economies in different regions:Africa (lbeh, 2003), Latin America (Alvarez, 2004; Lopez et al., 2009; Dib et al, 2010), and East Asia and the Pacific (Zou and Ghauri, 2010). They have identified born globals in both small and large markets, more developed and less advanced countries, noting that born globals have emerged in a wide range of locations.

The general findings of Kiss et al. (2012) reveal that born global firms from emerging economies pursue internationalization through not very systematically planned processes and are more likely to be born regional than born global, with certain exceptions. The factors that contribute to successful small firm internationalization range from government export promotion and the needs of technology. The most successful born globals, in general, adopt strategic alliances and networking activities that enable them to access critical resources and knowledge while adjusting to the varied institutional environments. Other factors such as the institutional environment are also important for successful startup and new venture growth (Bruton et al., 2008).

Another aspect that has drawn the attention of various researchers is the insertion of the high-tech born globals in a technology cluster or industrial district (Dib et al, 20 I0; Tan, 2006). Additionally, the integration in global chains, specifically a global production chain, is appearing in studies on accelerated internationalization from emerging markets. Hightech companies from emerging markets are being "pulled" by the trend of decentralization and outsourcing of the world high-tech industries.

Based on the international literature available, in the present study a list of external factors in the home environment was developed (Fernhaber et al, 2008). We have carefully chosen the studies that use the emerging market firms for their investigation, such as Kiss et al, 20 I2;Alvarez, 2004; Lopez et al., 2009; Dib et al., 20I 0; and Varma, $20 \mathrm{II}$.

The external factors tested in this study are the geographic location in the habitats of innovation (Becchetti and Rossi, 
2000; Servais et al., 2007; Dib et al, 2010; Zucchella at. al., 2007), the integration into global production chains (Goldstein; 200 I; Fernhaber et al., 2007; Giuliani et al., 2005; Servais et al., 2007), the partnerships and strategic alliances for innovation (Coviello, 2006; McDougall et al., 1994; Etemad, 2004; Dib et al, 2010; Zucchella at. al., 2007), and the governmental policies for internationalization (Alvarez, 2004; Fabian and Molina, 2009; Bell and McNaughton, 2000).

We have chosen these factors because they are discussed more frequently in the studies on born globals from the emerging economies. Although the industry characteristics (Bloodgood et al. 1996; Fernhaber et al., 2007; Bell and McNaughton 2000) and the limited domestic markets (Madsen and Servais 1997; Bell and McNaughton 2000) are important external factors, we are not testing them in this study. Fernhaber et al. (2007) conducted a study in the United States and has identified more than 20 industry structure variables that may influence the likelihood of new venture internationalization. The complexity and variety of these industry factors precludes the possibility of testing them here. The influence of limited domestic markets on the born globals is a common factor studied in the small countries from Europe (Gabrielsson, et al., 2004), and it would not make sense to explore this issue in a large market such as Brazil. Brazil is South America's largest country, has the world's 5th largest population and possesses the 6th largest GDP in the world behind the U.S., China, Japan, Germany, and France (World Bank, 20I2).

\section{Research hypotheses}

Studies demonstrate the importance of the geographic location of the company, especially in terms of participating in a habitat for innovation in the home country (Etzkowitz et al., 2005). A habitat for innovation is a planned site for the purpose of supporting the development of new businesses, providing a variety of services, supporting entrepreneurship and creating new ventures. It can be a technology park or a business incubator (Lee, 2000). The literature has underlined the importance of these firm agglomerations in providing a favorable environment for the rapid internationalization of smaller firms (Gilbert et al., 2008; Dib et al., 2010; Becchetti and Rossi 2000; Suzuki et al., 2002).

Fernhaber et al. (2008) suggest a gap in the literature on the importance of the geographical location in the internationalization process of young and small companies. This gap is surprising given the growth of such areas as Silicon Valley and Research Triangle in the U.S., as well as the increase in similar areas in countries around the world (Fernhaber et al., 2007a; Suzuki et al., 2002). The geographical location of the company, especially the innovative habitat in the home country (i.e., being a part of a technological park, business incubator, etc.), seems to be associated with rapid internationalization. In other words, the geographical concentration of the TBFs in habitats of innovation (Zucchella et al. 2007; Dib et al., 2010) may encourage their accelerated internationalization. The geographical concentration in innovative habitats fosters the creation of networks among companies, which allows them to face the challenges of technological complexity and the costs of research activities together.

$\mathrm{HI}:$ The location in innovation habitats is associated with the type of internationalization process followed by the TBFs, whether traditional or accelerated.

In addition, the dynamics of an industry have been indicated as differentiating accelerated internationalization from the traditionally internationalized firms (Zahra and George, 2002; Madsen and Servais, 1997; Fernhaber et al., 2007). Integration into a global industry (Fernhaber et al., 2007), specifically a global production chain, is appearing in studies on accelerated internationalization from emerging markets. For example, Brazilian studies demonstrate the integration of new ventures into the global production chains, such as in the software industry (Giuliani et al., 2005). Exports from the Brazilian software industry are modest but are being "pulled" by the trend of decentralization and outsourcing of the world software industry. Another example is the aircraft manufacturing sector. Due to the increasing technological complexity, reflected in the high costs of product development, aircraft manufacturers, such as Brazil's Embraer, have focused on design and assembly, demanding a wide range of components and services from a global supply chain (Goldstein, 200I; Fernhaber et al., 2007). Embraer's suppliers in Brazil have a high dependence on the company, which accounts for more than $90 \%$ of their revenues. The companies subcontracted by Embraer are generally small, with less than 50 employees, but with a high level of expertise in engineering, machining, and surface treatment. In recent years, the industry initiated a consolidation process, including the formation of a consortium of small and medium enterprises focused on export, called High Technology Aeronautics (HTA). This trend indicates how these companies are seeking international routes by associating with the global production chain of the aircraft manufacturer (Apex-Brazil, 2012).

The new ventures that emerge in these conditions need to think of a rapid internationalization strategy (Fernhaber et al., 2007). In such cases, the companies are "pulled" to the international market (Bell and McNaughton, 2000). Thus, the new venture has to internationalize rapidly, in response to their clients' demands (Fernhaber et al., 2007).

$\mathrm{H} 2$ : The integration into global production chains is associated with the type of internationalization process followed by the TBFs, whether traditional or accelerated. 
The role of partnerships in the home country is another recurrent theme in the studies of accelerated internationalization. The partnerships can happen with other local or multinational companies, universities or research institutions (Oviatt and Mcdougall, 1994; Dib et al., 2010; Autio et al., 2000). Coviello (2006) has observed that partnerships both generate resources and are a resource in their own right. Several recent studies grounded in the RBV have highlighted the way that firms acquire crucial resources for early internationalization from external network actors (Fahy, 2002).

The objectives of these partnerships range from the reduction of risks to the combination of essential resources, such as for the joint development of R\&D programs, etc. (Fernhaber et al., 2008). In small companies, given the limited organizational power and resource variety, local connections in the home country are extremely important for competitiveness and innovation (Fernhaber et al., 2008). In addition, an increasing number of large multinational companies, in pursuit of resources to facilitate innovation and capture ideas generated abroad, complement their R\&D by building strategic alliances with specialized new ventures in other countries (Vapola et al, 2008).

H3: Partnerships with multinational companies, universities and research institutions for innovation in the home country are associated with the type of internationalization process followed by the TBFs, whether traditional or accelerated.

In the literature, certain countries are taken as a reference in the formulation of specific policies for the expansion of companies that have already merged with the international market, such as Ireland, Australia, and Korea (Bell and Mcnaughton, 2000; Loane and Bell, 2006). Studies explaining new ventures using government policies for rapid internationalization (Bell and Mcnaughton, 2000) are not typical research. However, government policies have appeared in accelerated internationalization studies, specifically in the literature on the new ventures from emerging markets (Alvarez, 2004; Fabian and Molina, 2009).

Policies that encourage the internationalization of domestic companies can be implemented in several ways, but they generally reflect governmental support for exportation (Bell and Mcnaughton, 2000). Such governmental support for internationalization seems to be recurrent in studies of accelerated internationalization in emerging markets. For example, recent governmental policies in Brazil have encouraged the internationalization of domestic companies. APEX (the Brazilian Agency for Export Promotion and Investment) and BNDES have provided incentives in this direction (ApexBrazil, 2012). In China, research results suggest that supportive governmental policies are motivators for outward FDI of new ventures in the high-technology sectors seeking strategic assets and markets (Zou and Ghauri, 2010).
Start-ups, especially when they involve high technology, are the target of several initiatives aimed at reducing the costs of R\&D activities, especially in terms of the tax benefits with an emphasis on cooperative projects. The same has happened in relation to the internationalization of this type of company (Bell and Mcnaughton, 2000). Often, new ventures seek internationalization to gain access to an environment that fosters greater learning in terms of its technology (Bell and McNaughton, 2000) and are supported by their government (Chaminade and Vang, 2008).

There is still limited understanding of the impact of government policies on the internationalization process of born globals (Loane and Bell, 2006). Often, statements are not based on empirical evidence because few researchers have investigated the relationship between public policies and internationalization, especially regarding the competitive benefits for the firms and developmental benefits for the country.

$\mathrm{H} 4$ : The use of government policies is associated with the type of internationalization process followed by the TBFs, whether traditional or accelerated.

\section{Methodology}

We tested the hypotheses using the survey data from young and small technology-based firms (TBFs) in Brazil. We focused on the high-technology sectors because they have been emphasized by the most prominent studies of accelerated internationalization (Knight and Kim, 2009).

It is challenging to consolidate a statistically representative sample of young and small TBFs due to the lack of official census and the complete records of this type of firm. Therefore, we drew the sample in Brazil from the most reliable sources possible: (I) the National Association of Entities Promoting Advanced Technology Ventures (ANPROTEC), which is known for supporting young and small TBFs from the high-technology sectors, and (2) records of the government programs from the Brazilian Trade and Investment Promotion Agency (APEX) aimed to provide incentive to internationalization in the high-technology sectors. The ANPROTEC has associations with 90 technological parks and 384 incubators.

We had four sampling criteria:The firms had to be (I) not more than 10 years old - the 10-year upper limit is consistent with the previous research on entrepreneurial firms (Autio et al, 2000); (2) small Brazilian companies according to the IBGE (Brazilian Geography and Statistics Institute), so companies with more than 50 employees were excluded; (3) involved in developing, commercializing, or manufacturing high technology, according to the classification from the 
Organization for Economic Cooperation and Development (OECD, 2003), in Aeronautics and aerospace, pharmaceuticals, computer, electronics and telecommunications, and optical and precision; and (4) companies with any type of operation in at least one foreign market, including export to greenfield ventures. Because the TBFs depend on exports as their main mode of entry into international markets, most of the samples of international research on the phenomenon of accelerated internationalization use the databases of exporting companies (Knight and Kim, 2009).

Due to the uncertainty of the number of TBFs, the nature of the sample in this study did not aim to meet the criteria for statistical representativeness of the population, thereby constituting a non-probabilistic and intentional sample (Hair et al., 2005).

The questionnaire was developed with a five-point Likert scale. Each of the operational variables was related to at least three interval-level questions. Pre-tests were conducted with three executives of the TBFs, and we asked them to closely review the survey. Next, the questionnaire was sent to the founder (entrepreneur) or an executive, who works directly with the international operations of each TBF. The questionnaire was available on the Internet in June and July of $201 \mathrm{I}$.

We received responses from 214 of the approximately 800 firms. A precise number of TBFs could not be defined because the invitations to answer our questionnaire were sent by the managers of the incubators and technology parks. ANPROTEC helped advertise the research on their web site with a direct link to the questionnaire. We could not control how many companies had access to that the questionnaire. The first database generated had 214 answers. Of these 214 , II 4 questionnaires were from companies with operations exclusively in Brazil and were therefore excluded because they did not meet all sampling criteria; 85 (39.7\%) were from companies that had some type of foreign business. However, 31 of these 85 questionnaires had a large number of missing values. Thus, a decision was made to eliminate questionnaires with missing values from the analysis (Hair et al., 2005). In the end, 54 valid questionnaires were considered, although the analysis of the outliers for the statistical analysis reduced the number of questionnaires to 48 .

\section{Constructing Variables}

In this study, we consider accelerated internationalization: a maximum of 5 years from the inception to the initial revenues from international operations. The period from the company's foundation and the first foreign operation varies from 2 to 15 years: 2 years (Moen and Servais, 2002); 3 years (Kinight and Kim, 2009); 5 years (Zucchella et. al.,
2007; Dib et al. 2010); 6 years (Zahra and George, 2002); 8 years (Mcdougall et al., 1994); and 15 years (Gabrielsson et al, 2004). Five years was adopted to be able to followup another existing Brazilian study (Dib et al., 20l0). Therefore, adopting the same criteria used in most US and European studies (i.e., less than 5 years) would not increase the comparability of our study because the effort required from the Brazilian firms to export (compared, for example, to the European firms) is unbalanced. There was no restriction on the percentage of income from the foreign operations. In addition, there were no restrictions regarding the market scope or the countries covered, as most companies have a regional scope and cover a few countries (an average of two to three).

The independent variable External factors of the company was built in accordance with the models of Madsen and Servais (1997), Zahra and George (2002), Fernhaber et al. (2008). The following constructs impact the internationalization process of the TBFs:

Location of an innovation habitat (Cronbach's Alpha 0.780): This construct was adapted from the study of Fernhaber et al. (2008), who consider the location of an innovation habitat, such as a technological park or incubator. Thus, the construct was formed by four variables: Being part of an innovation habitat facilitated the company's internationalization; the company uses the name of its innovation habitat to be recognized in the international market; its innovation habitat provided strategic planning advice for the company to operate abroad; and the support of resources (the equipment, laboratories, specialized services, commercial structure to purchase inputs and sell products) from the innovation habitat influenced the internationalization of the company.

Integration into the global production chains (Cronbach's Alpha 0.814): This construct was related to the articulation of the company as a supplier in the global production chains or the competition in a highly internationalized sector (Fernhaber et al., 2007). Thus, the construct consists of five variables: Operating in a sector integrated internationally accelerated the need for the internationalization of the company; being a supplier of a product or service of a large multinational company accelerated the internationalization of the company; to compete in the sector, the internationalization of the company's activities is a matter of survival; the internationalization of the company's main client generated the need for a rapid internationalization of the company to continue as the supplier; and competing in a sector where the direct competitors operate abroad has accelerated the internationalization of the company.

Strategic partnerships and alliances for innovation (Cronbach's Alpha 0.7I5): This construct was adapted from the 
study by Coviello (2006), who demonstrates different ways of using partnerships to enter into the international markets. For this variable, we analyzed the company's partnerships in its home country. Thus, the questions verify the support in the internationalization of partnerships with Brazilian universities; joint R\&D projects with multinational companies located in Brazil; and partnerships with Brazilian research centers or institutions.

Government policies (Cronbach's Alpha 0.613): This construct was based on Bell and Mcnaughton (2000), who show the use of government policies (i.e., projects and funding) to support the internationalization. The questions grant support in the internationalization of the use of public funding to operate abroad; the participation in the projects of government entities in support of exportation; the international agreements held by the Brazilian government; and the tax policies of the Brazilian government.

\section{Statistical Techniques}

In this study, the logistic regression model was estimated to assess whether and to what extent each one of the independent variables contributes to the type of internationalization of the TBF (accelerated or traditional). The significance of the coefficients of the independent variables of the external factors was tested using the Wald statistics, and it was found that with a level of statistical significance of $p<0.05$, the coefficient is useful for the model (Hair et al., 2006). The significance of the final model can be found in the Hosmer and Lemeshow measure of overall fit, whose focus is not to reject Ho: There is no significant difference between the observed and predicted classifications.

To continue the data analysis and attempt to identify a set of companies with different types of influences in relation to the factors, we performed a cluster analysis of the logistic regression results. The purpose was to classify the clusters with the empirical base (Hair et al., 2006) for the interna- tionalization of the technology-based companies. The most traditional use of cluster analysis has been applied for exploratory purposes and for the formation of a taxonomy. Furthermore, the cluster analysis cannot be generalized, as it is completely dependent on the variables used as a basis for the measure of similarity.

We conducted an extraction through the hierarchical method, which indicated the possible existence of three clusters into which the sample could be divided, according to the pattern of the coefficients of homogeneity (between groups) and the Pearson correlation (farthest neighbor). After we obtained the result, we conducted a K-means cluster analysis, arriving at a combination of three clusters as the most suitable to explain this sample.

\section{Results and discussion}

Forty-eight TBFs were considered. Initially, we identified and separated the TBFs in terms of their internationalization processes. We identified 33 (69\%) companies that had an accelerated internationalization - that is, internationalized companies that met the research criteria (those that took less than 5 years to operate abroad). Fifteen companies $(31 \%)$ were classified as traditional international - that is, internationalized TBFs that entered the international market with more than 5 years of operation in the domestic market. Table 3 presents the means, standard deviations and results of the correlations made with the independent variables of the model. In general, the mean of the constructs habitat, partnership and integration is approximately three. Only the government political support is below two, demonstrating the general lack of this support for the TBFs. Except for the average and significant correlation between the political support and innovation habitat, the correlations presented here are poor and non-significant. This finding suggests that there is little possibility of multi-collinearity among the constructs presented.

\begin{tabular}{|l|l|l|l|l|l|l|l|}
\hline & & Mean & Std. Deviation & 1 & 2 & 3 & 4 \\
\hline 1 & LOC & 2.97 & 0.993 & 1.000 & & & \\
\hline 2 & INT & 3.07 & 0.904 & .184 & 1.000 & & \\
\hline 3 & PAR & 2.48 & 0.982 & .115 & .072 & 1.000 & \\
\hline 4 & POL & 1.86 & 0.773 & $.461^{* *}$ & .201 & .245 & 1.000 \\
\hline & $\mathrm{n} 48$ & & & & & & \\
\hline
\end{tabular}

Table 3: Correlations of the independent variables of the model $*_{p}<0.05 * *^{*}<0.01$ Source:Authors

ISSN: 07 I8-2724. (http://www.jotmi.org)

Journal of Technology Management \& Innovation (c) Universidad Alberto Hurtado, Facultad de Economía y Negocios. 
Table 4 presents the logistic regression model, where the coefficients of the logistic function for the external factors are indicated.The results for the regression model indicated a high explanatory power of $79 \%$. This result indicates that the external environment factors have a great prediction power to explain the strategic behavior of the TBFs.

According to Table 4, all of the independent variables of the external factors indicated significance $(p<0.05)$ for the internationalization process of the TBFs. However, the variables location in innovation habitat, partnerships and strategic alliances for innovation and government policies have a negative sign of coefficient $\mathrm{B}$, which contradicts the theoretical model. The analysis of the coefficient sign of these variables reveals that the longer the company takes to internationalize, the more the company can take advantage of the support from its habitat for innovation, partnerships and policies in the home country to operate in foreign markets. This is different from the theoretical model.

The results indicate that the factors listed in Table 5 are the most relevant factors to explain the internationalization process of the young and small Brazilian TBFs. All of the external factors studied here indicate relevance in the internationalization process of the TBFs.
Among the factors related to the external environment that influence the decision of an accelerated internationalization is the integration into a global production chain. In other words, the TBFs integrated in a global chain tend to follow a faster internationalization process.

The acceleration of the internationalization process of the TBFs due to the integration of the company into global production chains is in line with a few studies highlighting the new ventures that either arise as suppliers of a large multinational organization or arise in highly globalized sectors. In general, these TBFs are in sectors in which the global supply chains are configured, such as the aviation or software industry, among others (Fernhaber et al., 2007). Companies that arise in these industries at a particular time by virtue of the demands of their customers need to develop an internationalization strategy quickly. The TBFs examined here that had an accelerated internationalization process appear to be rapidly "pulled" into the international market because of the conditions and supply needs of their foreign clients (Fernhaber et al., 2007).

With regard to the external factors, another interesting result appears from this study: three of the four hypotheses tested for the external factors were proven to be reversed.

\begin{tabular}{|c|c|c|c|c|c|c|c|c|}
\hline & \multirow[b]{2}{*}{ B } & \multirow[b]{2}{*}{ S.E. } & \multirow[b]{2}{*}{ Wald } & \multirow[b]{2}{*}{$d f$} & \multirow[b]{2}{*}{ Sig. } & \multirow[b]{2}{*}{$\operatorname{Exp}(B)$} & \multicolumn{2}{|c|}{ 95\% C.I. for EXP(B) } \\
\hline & & & & & & & Lower & Upper \\
\hline LOC & -2.496 & 1.097 & 5.182 & 1 & .023 & .082 & .010 & .707 \\
\hline INT & 5.509 & 2.129 & 6.695 & I & .010 & 246.976 & 3.804 & 16.034 .377 \\
\hline PAR & -2.616 & 1.039 & $6.34 I$ & I & .012 & .073 & .010 & .560 \\
\hline POL & -3.028 & 1.259 & 5.787 & I & .016 & .048 & .004 & .571 \\
\hline Constant & 6.081 & 2.712 & 5.029 & I & .025 & 437.475 & & \\
\hline R Nagelkerke & 0.799 & & & & & & & \\
\hline \multicolumn{2}{|c|}{ Hosmer $=2.521 \quad(p>0.05)$} & & & & & & & \\
\hline \multicolumn{3}{|c|}{$\%$ of correct classifications $=92 \%$} & & & & & & \\
\hline
\end{tabular}

Table 4: Logistic regression - external environment factors Source:Authors

\begin{tabular}{|l|l|}
\hline External Factors & Results \\
\hline HIa:The location in habitats for innovation accelerates the entry of TBFs abroad. & $\begin{array}{l}\text { Supported, but } \\
\text { inverted }\end{array}$ \\
\hline HIb:The integration into global production chains accelerates the entry of TBFs abroad. & Supported \\
\hline $\begin{array}{l}\text { HIc:The use of partnerships with multinational companies, universities and research insti- } \\
\text { tutes for innovation in their country of origin accelerates the entry of TBFs abroad. }\end{array}$ & $\begin{array}{l}\text { Supported, but } \\
\text { inverted }\end{array}$ \\
\hline HId:The use of government policies and support accelerates the entry of TBFs abroad. & $\begin{array}{l}\text { Supported, but } \\
\text { inverted }\end{array}$ \\
\hline
\end{tabular}

Table 5: Summary of the hypotheses test related to the external factors. Source:Authors

ISSN: 07I 8-2724. (http://www.jotmi.org)

Journal of Technology Management \& Innovation (c) Universidad Alberto Hurtado, Facultad de Economía y Negocios. 
Therefore, most of the external factors have an influence on the internationalization process of the TBFs, but they are not the relevant factors for the TBFs to follow a rapid internationalization process. This finding indicates that the more experience the TBF has in the domestic market, the more it can benefit from certain factors in its internationalization process, such as location in an innovation habitat, partnerships with universities, research institutes and multinational companies, and government policies that support internationalization.

The results demonstrate that location is significantly more important in the internationalization process of companies that entered the international market after 5 years of experience in the Brazilian market. The location in an innovation habitat has been an efficient mechanism to facilitate access to typically difficult, sophisticated equipment, technological services, professional training, commercial structures for the purchase of inputs, sale of products, etc. (Suzuki et al., 2002; Lee, 2000). The results indicate that the older TBFs operating in the domestic market can take more advantage of the resources and support of the innovation habitat in their internationalization process. This can be explained by the higher articulation the company achieved throughout its development.

Regarding partnerships, the results indicate that the TBFs that internationalize after 5 years of activity benefit more from their innovation partnerships with other organizations in Brazil than the companies that internationalized before the 5 years of activity. Fernhaber et al. (2008) also present studies that found that in small enterprises, given the limited organizational strength and the limitation of resources of various types, the local connections in the home country are extremely important. Thus, the partnerships and alliances open internationalization opportunities for the TBFs and may involve connections with companies, research institutes, and universities.
One explanation for the reversal of this result is the fact that the TBFs with more experience in the domestic market would have long-standing business bonds, making it easier to use partnerships to enter the international market. The intense use of alliances allows the companies to face the increasing technological complexity and costs of research activities, as the TBFs are in high-tech industries of scientific knowledge (Fernhaber et al., 2007). In addition, the TBF can use its innovation partnership with a multinational to go abroad. The partnership between a multinational and a TBF is presented as a new phenomenon that occurs when the large multinationals, located in the TBFs' home country, want to complement their R\&D areas and therefore seek strategic alliances (Vapola et al, 2008). The TBFs with this partnership and technological learning can enter the foreign market more quickly.

Similarly, the TBFs that enter the international market after 5 years of activity are able to significantly take more advantage of the government policies for internationalization than the firms with an accelerated internationalization. A question that arises out of this result is whether the specific policies for internationalization created by the Brazilian government would reach smaller technology-based start-ups.

\section{Cluster Analysis}

To extend the analysis to verify the factors regarding the external environment in the internationalization of the TBFs, a cluster analysis was conducted. The result is displayed in Table 6. It is possible to observe three different groups of companies: a group of 14 companies (cluster 3 ) with mostly traditional internationalization, another group with $23 \mathrm{com}$ panies (cluster 2) where all except one are accelerated internationalization, and a group with only II companies (cluster I), of which approximately $75 \%$ have accelerated internationalization.

\begin{tabular}{|c|c|c|c|}
\hline \multicolumn{3}{|c|}{ Final Cluster Centers } \\
\hline & Cluster I & Cluster 2 & Cluster 3 \\
\hline LOC & 1.86 & $\begin{array}{c}\text { Born global TBFs integrated into } \\
\text { the value chain }\end{array}$ & Non-born global TBFs \\
\hline INT & 2.31 & 3.06 & 3.7 I \\
\hline PAR & 2.69 & 3.42 & 3.11 \\
\hline POL & 1.24 & 1.88 & 3.32 \\
\hline N & 11 & 1.75 & 2.55 \\
\hline $\mathrm{n}>5$ years & 3 & 23 & 14 \\
\hline $\mathrm{n}<5$ years & 8 & $\mathrm{I}$ & $\mathrm{II}$ \\
\hline
\end{tabular}

Table 6: Clusters. Source:Authors

ISSN: 07 I8-2724. (http://www.jotmi.org)

Journal of Technology Management \& Innovation (c) Universidad Alberto Hurtado, Facultad de Economía y Negocios. 
Continuing the analysis, Table 7 displays the analysis of variance test (Tukey's post hoc) to identify the distinction of the three clusters obtained in the previous table.

The TBFs in cluster I make use of partnerships established in their home country to internationalize in an accelerated manner.These partnerships are significantly $(p<0.05)$ greater than the companies in cluster 2 and are on the same level as the companies in cluster 3 .

Cluster 2, characterized by the vast majority of accelerated internationalization, stands out in relation to the other clusters for being the group that can make greater use of integration in the value chain of the industry. These TBFs are suppliers of a large multinational company or are in highly globalized sectors, such as aviation, automotive, and software, among others (Fernhaber et al., 2007).

Finally, Cluster 3 was called traditional internationalization. It is possible to notice that the location and government policy factors have a greater impact $(p<0.05)$ on the internationalization process when compared with the companies in clusters I and 2. The partnership factor has a greater impact $(p<0.05)$ only when compared with the companies in cluster 2 , while integration has a greater impact $(p<0.05)$ only in relation to cluster I.Therefore, it is possible to conclude that traditional internationalized TBFs differ from the accelerated TBFs in their internationalization process by making better use of factors such as location and government policy.

\section{Conclusion}

The results demonstrated that the environmental variables appear to be associated with the type of internationalization process chosen by these firms. The results suggest that the new and small Brazilian technology-based firms, which followed an accelerated internationalization process, are most likely to be integrated into a global production chain. It was also found that compared to the TBFs with an accelerated internationalization process, the TBFs that take more than 5 years to internationalize benefit more from the location in an innovation habitat, the partnerships with universities, the research institutions and multinational companies, and the pro-internationalization government policies.

The limitations of this study must be recognized. First, we used a non-probabilistic sample, which prevents the researcher from calculating a statistically liable sample. The aim was to build a comprehensive sample, mainly regarding the coverage (I) of sectors in which the activities of high technology TBFs are normally developed and (2) of the main regions in Brazil where there are previous indications of the existence of this type of company. The number of TBFs in Brazil has expanded in recent years, due to the government and the entities promoting entrepreneurship and internationalization. However, it is necessary to note the reduced number of Brazilian TBFs that have some type of business abroad. The second limitation of the study is that most of the data collected were based on the perceptions of the respondents.

\begin{tabular}{|c|c|c|c|c|c|c|c|}
\hline \multirow[b]{2}{*}{ Variable } & \multirow{2}{*}{$\begin{array}{l}\text { Cluster } \\
\text { Number } \\
\text { of Case }\end{array}$} & \multirow{2}{*}{$\begin{array}{l}\text { Cluster } \\
\text { Number } \\
\text { of Case }\end{array}$} & \multirow[b]{2}{*}{ Mean Difference (I-J) } & \multirow[b]{2}{*}{ Std. Error } & \multirow[b]{2}{*}{ Sig. } & \multicolumn{2}{|c|}{ 95\% Confidence Interval } \\
\hline & & & & & & $\begin{array}{l}\text { Lower } \\
\text { Bound }\end{array}$ & Upper Bound \\
\hline \multirow[t]{3}{*}{ LOC } & \multirow[t]{2}{*}{1} & 2 & $-1.19864^{*}$ & .27545 & .000 & -1.8662 & -.5311 \\
\hline & & 3 & $-1.85065^{*}$ & .30274 & .000 & -2.5844 & -1.1169 \\
\hline & 2 & 3 & $-.6520 I^{*}$ & .25470 & .036 & -1.2693 & -.0347 \\
\hline \multirow[t]{3}{*}{ INT } & \multirow[t]{2}{*}{$\mathrm{I}$} & 2 & $-1.11434^{*}$ & .29528 & .001 & -1.8300 & -.3987 \\
\hline & & 3 & $-.81050^{*}$ & .32454 & .042 & -1.5970 & -.0239 \\
\hline & 2 & 3 & .30384 & .27304 & .511 & -.3579 & .9656 \\
\hline \multirow[t]{3}{*}{ PAR } & \multirow[t]{2}{*}{$I$} & 2 & $.81036^{*}$ & .28318 & .017 & .1240 & 1.4967 \\
\hline & & 3 & -.62283 & .31124 & .124 & -1.3772 & .1315 \\
\hline & 2 & 3 & $-1.43320^{*}$ & .26185 & .000 & -2.0678 & -.7986 \\
\hline \multirow[t]{3}{*}{ POL } & \multirow[t]{2}{*}{1} & 2 & -.50938 & .22443 & .071 & -1.0533 & .0345 \\
\hline & & 3 & $-1.31255^{*}$ & .24666 & .000 & -1.9104 & -.7147 \\
\hline & 2 & 3 & $-.80317^{*}$ & .20752 & .001 & -1.3061 & -.3002 \\
\hline
\end{tabular}

Table 7:ANOVA - Post Hoc Test. Source:Authors

ISSN: 07I 8-2724. (http://www.jotmi.org)

Journal of Technology Management \& Innovation (c) Universidad Alberto Hurtado, Facultad de Economía y Negocios. 
We expect our findings to apply broadly to accelerated internationalization from other emerging markets such as China, India, Mexico, etc. We encourage future research to extend our findings. Furthermore, little is known about what happens to the evolution and survival of firms that have an accelerated internationalization process.

\section{References}

ALVAREZ, E.R., 2004. Sources of export success in small and medium sized enterprises: the impact of public programs. International Business Review 13 (3),383-400.

APEX- Brazil (20I2). Brazilian Federal Export and Investment Promotion Agency. Projects for High Technology and Health.Available at: http://www.apexbrasil.com.br/portal/.

ANPROTEC (20I I). Associação Nacional de Entidades Promotoras de Empreendimentos Inovadores. Retrieved from: http://www.anprotec.org.br

AUTIO, E., Sapienza, H., Almeida, J. (2000). Effects of age at entry, knowledge intensity, and imitability on international growth. Academy of Management Journal, 43, (5), 909-924.

BECCHETTI, L.; Rossi, S. P. (2000). The positive effect of industrial district on the export performance of Italian firms. Review of Industrial Organization, 16(I), 53-68.

BELL, J., McNaughton, R. (2000). Born global firms: a challenge to public policy in support of internationalization. Marketing in a Global Economy, I76- I85.

BLOODGOOD, J. M., Sapienza, H. J., Almeida, J. G. (1996). The internationalization of new high-potential US ventures: Antecedents and outcomes. Entrepreneurship Theory and Practice, 20, 6I-76.

BRUTON, G. D., Ahlstrom, D., Obloj, K. (2008). Entrepreneurship in emerging economies: Where are we today and where should the research go in the future. Entrepreneurship theory and practice, 32(I), I-I4.

CHAMINADE, C., Vang, J. (2008). Globalisation of knowledge production and regional innovation policy: Supporting specialized hubs in the Bangalore software industry. Research Policy, 37(10), I684-I696.

COVIELLO, N. E. (2006). The network dynamics of international new ventures. Journal of International Business Studies, 37(5), 7|3-73I.
DIB, L.A., Rocha, A., Silva, J. F. (20I0). The internationalization process of Brazilian software firms and the born global phenomenon: Examining firm, network, and entrepreneur variables. Journal of International Entrepreneurship, 8 (3), 233-253.

DUNNING, J. H. (1980). Toward an eclectic theory of international production: Some empirical tests. Journal of International Business Studies, I I(I), 9-3I.

ETZKOWITZ, H., de Mello, J. M. C., Almeida, M. (2005). Towards "meta-innovation" in Brazil:The evolution of the incubator and the emergence of a triple helix. Research Policy, 34(4), 4 I I-424.

FABIAN, A. P. F., Molina, H. (2009). Understanding decisions to internationalize by small and medium-sized firms located in an emerging market. Management International Review, 49(5), 537-563.

FAHY, J. (2002) 'A Resource-based Analysis of Sustainable Competitive Advantage in a Global Environment', International Business Review I I ( ): 57-77.

FERNHABER, S. A., Gilbert, B. A., McDougall, P. P. (2008). International entrepreneurship and geographic location: an empirical examination of new venture internationalization. Journal of International Business Studies, 39(2), 267-290.

FERNHABER, S. A., McDougall, P. P., Oviatt, B. M. (2007). Exploring the role of industry structure in new venture internationalization. Entrepreneurship Theory and Practice, 3 I (4), 517-542.

GABRIELSSON, M.; Sasi,V.; Darling, J. (2004). Finance strategies of rapidly-growing finnish SMEs: born internationals and born globals. European Business Review, 16, 590-604.

GIULIANI, E., Pietrobelli, C., Rabellotti, R. (2005). Upgrading in global value chains: lessons from Latin American clusters. World development, 33(4), 549-573.

GOLDSTEIN, A. (200I). From national champion to global player: explaining the success of Embraer. Centre for Brazilian Studies, University of Oxford.

GILBERT, B.A., McDougall, P. P.,Audretsch, D. B. (2008). Clusters, knowledge spillovers and new venture performance:An empirical examination. Journal of Business Venturing, 23(4), 405-422. 
GUILLÉN, M., García-Canal, E. (2009) The American Model of the Multinational Firm and the "New" Multinationals from Emerging Economies.Academy of Management Perspectives, 23(2), 23-35.

HAIR, J., Black, W., Babin, B., Anderson, R., Tatham, R. (2006). Análise Multivariada de dados. 6a. edição. Porto Alegre: Bookman.

IBEH, K. I. (2003). Toward a contingency framework of export entrepreneurship: conceptualisations and empirical evidence. Small Business Economics, 20(I), 49-68.

KANNA, T, Palepu, K. (2010). Winning in Emerging Markets: A Road Map for Strategy and Execution. Harvard Business School Publishing.

KEUPP, M. M., Gassmann, O. (2009). The past and the future of international entrepreneurship: a review and suggestions for developing the field. Journal of Management, 35(3), 600-633.

KISS, A. N., Danis, W. M., Cavusgil, S., (20I2). International entrepreneurship research in emerging economies:A critical review and research agenda. Journal of Business Venturing, 27 (2), 266-290.

KNIGHT, G. A, Kim, D. (2009). International business competence and the contemporary firm. Journal of International Business Studies, 40 (2), 255-273.

LEE, C. M. (Ed.). (2000). The Silicon Valley edge: A habitat for innovation and entrepreneurship. Stanford University Press. Loane, S., Bell, J. (2006). Rapid internationalisation among entrepreneurial firms in Australia, Canada, Ireland and New Zealand: An extension to the network approach. International Marketing Review, 23(5), 467-485.

LOPEZ, L. E., Kundu, S. K., Ciravegna, L. (2008). Born global or born regional\&quest; Evidence from an exploratory study in the Costa Rican software industry. Journal of International Business Studies, 40(7), I228-I 238.

MADSEN,T. K., Servais, P. (1997). The internationalization of born globals - an evolutionary process? International Business Review, 6, (6), 56I-583.

MOEN, O., Servais, P. (2002). Born global or gradual global? Examining the export behavior of small and medium-sized enterprises. Journal of International Marketing, I0(3), 49-72.

OCDE (2003). Science, Technology and Industry Scoreboard. Paris.
OVIATT, B. M., Mcdougall, P. P. (1994). Toward a theory of international new ventures. Journal of International Business Studies, 25 (I), 45-64.

PERSINGER, E. S., Civi, E., Vostina, S. W. (2007). The Born Global Entrepreneur In Emerging Economies. International Business \& Economics Research Journal, 6, (3), 73-82.

RAMAMURTI, R. (20I2). What is really different about emerging market multinationals?. Global Strategy Journal, 2(I), 4 I-47.

RIALP, A. C., Rialp, J. C., Knight, G. A. (2005). The phenomenon early internationalizing firms: what do we know after a decade (1993-2003) of scientific inquiry? International Business Review, I4, I47-I66.

SERVAIS, P., Zucchella, A., Palamara, G. (2007). International entrepreneurship and sourcing: international value chain of small firms. Journal of Euromarketing, I6(I-2), I05-I I7.

SUZUKI, K. I., Kim, S. H., Bae, Z.T. (2002). Entrepreneurship in Japan and Silicon Valley: a comparative study.Technovation, 22(10), 595-606.

TAN, J. (2006). Growth of industry clusters and innovation: Lessons from Beijing Zhongguancun Science Park. Journal of Business Venturing, $2 \mathrm{I}(6), 827-850$.

VAPOLA, T. J., Tossavainen, P., Gabrielsson, M. (2008). The battleship strategy: The complementing role of born globals in MNC's new opportunity creation. Journal of International Entrepreneurship, 6(I), I-2I.

VARMA, S. (20II). Born global acquirers from Indian IT: an exploratory case study. International Journal of Emerging Markets, 6(4), 35I-368.

WORLD BANK. (2012). World Development Indicators database, available at: http://databank.worldbank.org/databank/ download/GDP.pdf (accessed I2 May 2013)

ZAHRA, S., George, G. (2002). International entrepreneurship: the current status of the field and future research agenda. In: Hitt, M.; Ireland, R.; Camp, M.; Sexton, D. (Eds.). Strategic leadership: creating a new mindset. London, UK: Blackwell, 255-288.

ZOU, H.A., Ghauri, P. N. 20I0. Internationalizing by learning: the case of Chinese high-tech new ventures. International Marketing Review, 27(2): 223-44.

ZUCCHELLA, A., Palamara, G., Denicolai, S. (2007). The drivers of the early internationalization of the firm. Journal of World Business, 42(3), 268-280 